\title{
Aspectos relacionados ao uso de textos de Divulgação Científica em uma Sequência Didática na formação inicial de professores de Ciências e Biologia
}

\author{
Carlos Alberto Andrade Monerat ${ }^{1}$ \\ Marcelo Borges Rocha ${ }^{2}$
}

\begin{abstract}
RESUMO
Sequências Didáticas permitem ao estudante reestruturar conceitos aprendidos, gerando reflexões sobre sua aprendizagem, pois se apresentam como instrumentos de consolidação das relações entre teoria e práticas em sala de aula. Assim sendo, esta pesquisa envolveu a aplicação de uma Sequência Didática associada a textos de Divulgação Científica com um grupo de licenciandos em Biologia, investigando como esta associação pode contribuir com a formação de professores. Os dados foram coletados com base nos registros dos encontros e na análise dos materiais produzidos pelos participantes. Os resultados indicam que os textos utilizados se constituem em relevantes recursos no processo de formação dos licenciandos. As atividades propostas geraram discussões sobre questões que permeiam a construção necessária à prática educativa, permitindo também perceber que estes indivíduos devem se apropriar criticamente dos pressupostos científicos, ressignificando-os para sua utilização em atividades de ensino.
\end{abstract}

PALAVRAS-CHAVE: Sequência Didática. Divulgação Científica. Ensino de Ciências. Formação de Professores.

\footnotetext{
${ }^{1}$ Doutor em Ciência, Tecnologia e Educação. Centro Universitário Celso Lisboa, Rio de Janeiro, RJ, Brasil. https://orcid.org/0000-0001-7446-9889. carlos.monerat@gmail.com.

2 Doutor em Ciências Biológicas.CEFET-RJ, Rio de Janeiro, RJ, Brasil. https://orcid.org/0000-0003-4472-7423. rochamarcelo36@yahoo.com.br.
} 
Aspects related to the application of a Didactic Sequence with use of Science Disclosure texts in the initial formation of Science and Biology teachers

\begin{abstract}
Didactic Sequences allows the student to restructure concepts learned, generating reflections about their learning process, because it presents itself as a tool of consolidation of the relations between theory and classroom practices. Therefore, this research involved the application of a Didactic Sequence associated to Scientific Disclosure texts with a group of undergraduate Biology students, investigating how this association can contribute to the teachers' formation. The data were collected based on the meetings' records and the analysis of the materials produced by the participants. The results indicate the texts used constitute important resources in the process of training students. The proposed activities have generated discussions about questions that permeate the necessary construction to the educational practice, allowing also to realize that individuals should to appropriate critically of scientific presuppositions, re-signifying them for their use in teaching activities.
\end{abstract}

KEYWORDS: Didactic Sequence. Science Disclosure. Science Teaching. Teacher Formation.

\title{
Aspectos relacionados con la aplicación de una Secuencia Didáctica utilizando textos de Difusión Científica en la formación inicial de profesores de Ciencias y Biología.
}

\section{RESUMEN}

Las secuencias didácticas permiten al alumno reestructurar los conceptos aprendidos, generando reflexiones sobre su aprendizaje, ya que se presentan como instrumentos de consolidación de las relaciones entre la teoría y las prácticas en el aula. Por lo tanto, esta investigación implicó la aplicación de una secuencia didáctica asociada con textos de difusión científica con un grupo de graduados en biología, investigando cómo esta asociación puede contribuir a la formación de docentes. Los datos fueron recolectados en base a los registros de las reuniones y el análisis de los materiales producidos por los participantes. Los resultados indican que 
los textos utilizados constituyen recursos relevantes en el proceso de graduación de los alumnos. Las actividades propuestas generaron discusiones sobre temas que impregnan la construcción necesaria para la práctica educativa, lo que también nos permite darnos cuenta de que estas personas deben apropiarse críticamente de suposiciones científicas, volviéndolos a significar para su uso en las actividades de enseñanza.

PALABRAS CLAVE: Secuencia didáctica. Divulgación de la ciencia. Enseñanza de las Ciencias. Formación docente.

$$
* * *
$$

\section{Introdução}

A formação continuada de educadores deve ser permeada por momentos que gerem reflexões críticas sobre sua atividade. Objetivando este ininterrupto aprimoramento recomenda-se pensar cuidadosamente suas práticas anteriores e buscar, através de formas diversificadas de leitura e compreensão de suas realidades, efetivas transformações.

Segundo Zabala e Arnau (2007), variadas estratégias e atividades didáticas têm relevante papel para transposição de um ensino tradicionalista, expositivo e focado apenas na transmissão de informações, em um ensino contextualizado e significativo, aproveitando as vivências do estudante, incentivando uma postura questionadora e sua capacidade analítica. Este conjunto de fatores pode contribuir significativamente para uma adequada leitura e interpretação apropriada do mundo atual.

De acordo com Zabala (1998, p. 18), as Sequências Didáticas (SD) podem assumir esse posicionamento, pois segundo este autor, elas são instrumentos caracterizados como "[...] um conjunto de atividades ordenadas, estruturadas e articuladas para a realização de certos objetivos educacionais, que têm um princípio e um fim conhecidos tanto pelos professores como pelos alunos". 
Dolz, Noverraz e Schneuwly (2004) argumentam que as SD devem primar pela diversificação, seleção e adaptação das diversas atividades propostas, além da sua aplicação nos momentos pedagógicos propícios em função das necessidades dos alunos de se apropriarem dos conhecimentos em cada situação. Por isso, elas devem ser cuidadosamente selecionadas conforme o perfil pedagógico do grupo e da complementaridade em relação a outras situações de aprendizagem.

Desse modo, Zabala (1998) alega que as SD buscam considerar a importância das intervenções educacionais na construção dos conteúdos que devem ser aprendidos e no papel das atividades que são propostas, devendo ser planejadas e replanejadas, ao longo de todo o processo. Para o autor, as intenções educativas devem estar bastante claras, sempre em consonância com os conteúdos de aprendizagem, os quais devem ser pensados em função de uma realidade mais ou menos próxima dos alunos, contemplando todos os fatores envolvidos nela. A partir daí, então, serão elaboradas as atividades com objetivo de efetivar a aprendizagem, abrangendo, sempre que possível, dimensões conceituais, procedimentais; conceituais e procedimentais; ou até mesmo conceituais, procedimentais e atitudinais.

Seu planejamento e aplicação, segundo Giordan, Guimarães e Massi (2011), pode estabelecer um elo entre a pesquisa acadêmica e o ensino de disciplinas com conteúdos científicos, como Ciências e Biologia, em termos de melhor contextualizá-las, já que este campo de pesquisa possui diversidade investigativa enquanto instrumento de análise das interações da sala de aula ou nos pressupostos teóricos que envolvem sua elaboração, validação ou aplicação, sendo de interesse da área de Educação há bastante tempo.

Zabala e Arnau (2007) entendem que, para uma adequada utilização deste instrumento, os conteúdos de aprendizagem devem estar bem estruturados e colocados mediante uma realidade mais próxima dos alunos, contemplando-se todos os fatores envolvidos. Deve-se ter como base a 
sistematização das diferentes fases que o constituem, a partir de um pensamento complexo e na reiteração e na análise de situações diversas.

Por sua vez, a Divulgação Científica pode se tornar uma aliada na construção do conhecimento, pois pelas suas características, se estabelece através de uma variedade de veículos dos quais consegue dispor, possibilitando que a informação científica seja levada a diferentes públicos, em variadas situações, incluindo o estudantil, contando, assim, com uma considerável abrangência. Logo, Gomes (2000) e Bueno (2009) a definem como um instrumento que se utiliza de processos, estratégias, técnicas e mecanismos de veiculação de fatos e de informações que se situam no universo da ciência, da tecnologia e da inovação.

O viés didático que pode emanar das ações de Divulgação Científica apontado por Moreira (2006) é considerado um dos principais pontos de contribuição para a formação e inclusão científica de estudantes. Uma das questões que convergem a favor desse caráter é o fato da produção científica e tecnológica, nos últimos tempos ter se desenvolvido, principalmente por conta das recentes revoluções em áreas como a da informática e da automação, provocando consideráveis impactos socioeconômicos.

A Divulgação Científica permite que se leve a informação científica aos mais variados públicos, em diferentes locais, contando assim com uma considerável abrangência. Escolas e universidades, com acesso a este material, podem ser considerados potenciais colaboradores na formação da opinião sobre ciência e tecnologia. Monerat e Rocha (2018) chamam a atenção para o fato de que os textos de Divulgação Científica, através dos seus diversos formatos, trazidos em jornais, revistas, dentre outros meios, podem se tornar importantes instrumentos a serem utilizados em contexto educacional, formativo e inclusivo, desde que utilizados com criticidade e fundamentações bem estabelecidas.

Neste contexto as mídias impressas se apresentam como potencial auxiliar nos processos de aprendizagem, pois são responsáveis por grande parte das informações que as pessoas adquirem sobre questões diversas. 
Autores como Martins, Cassab e Rocha (2001); Martins, Nascimento e Abreu (2004); Goldbach e El-Hani (2008); Kemper, Zimmermann e Gastal (2010); chamam a atenção para o fato de que os textos de Divulgação Científica podem se tornar importantes instrumentos utilizados em contexto educacional e formativo, por meio dos seus diversos formatos, incluindo jornais, revistas, dentre outros, já que possuem vários recursos linguísticos e imagéticos, os quais aproximam seus conteúdos do público leitor.

De acordo com as perspectivas apresentadas, este trabalho buscou analisar os aspectos relacionados à aplicação de uma SD, utilizando-se de textos de divulgação científica, para a formação de futuros professores de Ciências e Biologia, no que se refere às questões relacionadas à natureza da ciência, aos recursos linguísticos e imagéticos, à identificação de possíveis erros conceituais e à interdisciplinaridade.

\section{Metodologia}

Para esta pesquisa pensou-se na elaboração e aplicação de uma SD envolvendo alunos de graduação de um curso de licenciatura em Ciências Biológicas, no sentido de investigar de que maneira estes estudantes se apropriam deste material e quais contribuições e até mesmo limitações esses textos podem apresentar para a formação do futuro professor de Ciências e Biologia.

Para atender as propostas acima, optamos por uma pesquisa descritiva, que segundo Gil (2008), é aquela que se direciona a apurar as interações entre os sujeitos participantes do processo, que podem estar representados por determinadas populações em relação a determinados fenômenos observados, sobre os quais se queira investigar. Ainda na conjuntura desta modalidade de pesquisa, Triviños (1987) afirma que esse tipo de pesqusia pretende descrever os fatos e fenômenos de determinada realidade, exigindo do investigador a coleta de uma série de informações sobre o que se almeja pesquisar. 
Para aplicação da SD foi constituído um grupo formado por dez estudantes de graduação, do curso de Licenciatura em Ciências Biológicas, de uma instituição particular de ensino superior, localizada na Cidade do Rio de Janeiro, Brasil. Os alunos fazem parte da turma do $5^{\circ}$ período do referido curso. A escolha do grupo para compor o presente estudo se deu a partir de observações relacionadas às dificuldades experimentadas por estes estudantes ao se apropriarem de determinados conceitos importantes para sua formação acadêmica, os quais abrangem tanto os conhecimentos técnicos, quanto a organização de ideias e pensamentos.

Ao trabalhar estes pontos foi pensada uma metodologia que pudesse despertar o senso crítico, analítico e ético a respeito dos assuntos de interesse destes futuros professores, estimulando debates e discussões, de modo a ampliar e consolidar a sua formação. Logo, a SD constou de seis encontros semanais com os alunos participantes, em datas previamente estipuladas, na própria sala de aula e no laboratório de Biologia da instituição, sendo os mesmos realizados após o horário das aulas, com duração média de duas horas cada um, totalizando doze horas de duração.

O fato da proposta contar com encontros após o horário regular das aulas e ter participação voluntária serviu para constatar que o grupo analisado demonstrou interesse em conhecer diferentes experiências durante a sua formação, pois este gesto evidenciou preocupações no aprimoramento das suas práticas de ensino, uma vez que, dentro em breve, estarão vivenciando a sua própria sala de aula.

Para a realização da SD, os participantes foram divididos em grupos, formando equipes de trabalho. Esta foi a maneira como todas as atividades foram realizadas, pois assim, os alunos puderam trocar conhecimentos durante o processo. Neste sentido, o levantamento de dados foi realizado tendo como base as anotações dos registros dos encontros, realizadas em um diário de bordo, bem como na análise dos materiais produzidos pelos participantes, sob a forma de textos, relatórios, leituras e planos de aula. 
Para cada encontro pensou-se, como princípio norteador do processo, na produção de atividades que envolvessem a utilização de textos de Divulgação Científica relacionados à Biologia Celular, publicados em revistas de grande circulação, e que levassem em consideração os pontos mais importantes para o contexto da formação desses alunos como futuros professores de Ciências e Biologia, proporcionando a eles condições de desenvolver leituras e análises críticas sobre temas diversos, e que pudessem estar voltados para suas próprias aulas.

A partir das atividades pensadas para a SD, era esperado, por parte dos envolvidos, a produção de um material correspondente, conforme mostrado no quadro 1 , em que foi possível reconhecer de que maneira os textos de Divulgação Científica contribuíram para a formação dos participantes enquanto professores leitores.

QUADRO 1: Organização dos encontros da Sequência Didática

\begin{tabular}{|c|c|c|}
\hline Encontro & Conteúdos/Assuntos abordados & Produção \\
\hline 1 & $\begin{array}{c}\text { Apresentação da pesquisa e orientação gerais sobre o } \\
\text { trabalho com a sequência didática. Preenchimento de } \\
\text { questionário prévio. }\end{array}$ & $\begin{array}{l}\text { Sensibilização dos } \\
\text { estudantes em relação à } \\
\text { pesquisa e as contribuições } \\
\text { com a sua formação. }\end{array}$ \\
\hline 2 & $\begin{array}{l}\text { Trabalho com textos que levem em consideração os } \\
\text { aspectos relacionados à natureza da ciência. }\end{array}$ & $\begin{array}{l}\text { Confecção de um texto sobre } \\
\text { o entendimento dos } \\
\text { participantes sobre os } \\
\text { aspectos relacionados à } \\
\text { natureza da ciência. }\end{array}$ \\
\hline 3 & $\begin{array}{l}\text { Utilização de textos envolvendo os temas mais abordados } \\
\text { pela mídia impressa na Biologia Celular, além da utilização } \\
\text { de textos contendo recursos imagéticos. }\end{array}$ & $\begin{array}{c}\text { Preparação de um plano de } \\
\text { aula teórica e prática para a } \\
\text { sala de aula e o laboratório } \\
\text { de Biologia. }\end{array}$ \\
\hline 4 & $\begin{array}{l}\text { Utilização de textos abordando temas multidisciplinares de } \\
\text { Biologia Celular. }\end{array}$ & $\begin{array}{l}\text { Preparação de um relatório } \\
\text { identificando os temas e a } \\
\text { importância da } \\
\text { interdisciplinaridade. }\end{array}$ \\
\hline 5 & $\begin{array}{l}\text { Utilização de textos contendo inconsistências e erros } \\
\text { conceituais. }\end{array}$ & $\begin{array}{c}\text { Atividade de leitura e } \\
\text { identificação dos erros } \\
\text { conceituais por parte dos } \\
\text { participantes, com } \\
\text { preparação de relatório. }\end{array}$ \\
\hline 6 & Encontro final. Preenchimento de questionário pós. & $\begin{array}{l}\text { Amostra dos materiais } \\
\text { produzidos pelos } \\
\text { participantes. }\end{array}$ \\
\hline
\end{tabular}

Fonte: Os autores, 2019

Desse modo, os dados coletados foram estudados à luz da Análise de Conteúdo, descrita por Bardin (2009, p. 42), que consiste em "um conjunto 
de técnicas de análise de comunicação que objetivam a obtenção, através de métodos sistemáticos e objetivos, das descrições relacionadas ao conteúdo das mensagens". Esta estratégia possibilitou a apuração das informações em um contexto mais adequado, uma vez que elas possuíam caráter descritivo e apresentavam complexidade, reveladas na diversidade de textos presentes nas revistas analisadas e nos dados coletados dos questionários durante as atividades da Sequência Didática.

\section{Resultados e discussão}

No primeiro encontro aconteceu uma apresentação expondo os aspectos concernentes à SD. É importante destacar que, segundo relatos próprios, os alunos participantes do processo não tinham noção sobre o que representa, em termos conceituais, a Divulgação Científica, tampouco contato com estes tipos de textos.

$\mathrm{Na}$ ocasião do segundo encontro aconteceu a primeira atividade programada, no qual foi sugerido um trabalho utilizando as revistas de Divulgação Científica que traziam matérias abordando aspectos relacionados à Natureza da Ciência. Em um primeiro momento foi realizada à leitura e, posteriormente, um debate sobre estas reportagens. Após esta etapa, o grupo construiu um texto demonstrando as suas ideias a respeito de questões concernentes à atividade científica e o que eles achavam sobre o papel da ciência para a sociedade. Nesta descrição deveria constar o entendimento deles sobre o que é ciência, como se faz ciência, que resultados poderiam ser esperados da atividade científica, para qual finalidade estaria voltada a ciência, e o que representaria a figura do cientista.

Ao analisarmos a produção dos alunos, podemos perceber que eles ainda têm uma visão ingênua a respeito da atividade científica, o que pode ser constatado com a leitura dos trechos de dois textos destacados e reproduzidos na íntegra: 
[...] um cientista é aquele profissional intocavél (sic), cheio de ideias geniais e únicas. Aquele cientista que fica manipulando tubos de ensaios fazendo experimentos para salvar o mundo. É aquele tal cientista maluco que vive no seu mundo singular, onde só fala palavras e termos que só eles mesmos entendem (PARTICIPANTE 2).

O cientista são (sic) profissionais que buscam descobrir algo novo na ciência para benefício de todos desde a descoberta da prevenção de uma doença até uma nova espécime (sic) de vida existente não descrita. No Brasil o cientista não é reconhecido como outros profissionais, em geral é inabitual indivíduos desejar (sic) ser cientista ,devido ao salário e a falta de investimento pelo governo (PARTICIPANTE 5).

Um fator chama a atenção sobre esta observação: estes textos pertencem a estudantes universitários concluintes em seus cursos de licenciatura em Biologia. Porém, apesar de estarem distantes de um entendimento adequado sobre a atividade científica, o papel do cientista e a Natureza da Ciência, devemos problematizar as percepções destes alunos, pois trabalhos como o de Kemper, Zimmermann e Gastal (2010) retratam justamente estas particularidades:

No imaginário popular, a ciência costuma ser vista, por um lado, como a salvação para todos os males e, por outro, como a causadora dos problemas - são as duas faces de Jano. Por um lado, há os que afirmam que as contribuições da mecânica, da física e da química para a Revolução Industrial e o desenvolvimento das ciências biológicas e da medicina experimental para o combate às doenças demonstram o quão importante a ciência é para a sociedade. Por outro lado, são crescentes os sentimentos de ceticismo e resistências à ciência e ao conhecimento por ela gerado. Atualmente temos, em muitos casos, uma visão caricata do que 
seja ciência e de sua importância, com uma forte crença na neutralidade e objetividade da ciência, o que não permite um discernimento mais claro do que sejam a ciência, a tecnologia e seus impactos (KEMPER; ZIMMERMANN; GASTAL, 2010. p. 28).

Além do desconhecimento sobre a Natureza da Ciência, é evidente a constatação no que concerne à insuficiência da leitura para estes futuros educadores. Esta verificação se mostra nos erros ortográficos e de concordância que aparecem nas linhas confeccionadas desta atividade. Segundo diversos autores, como Kleiman (2000); Santos (2006); Ferreira e Santos (2010); Monteiro (2014) a leitura é uma prática essencial para o domínio da língua vernácula e, consequentemente, uma boa escrita.

Após a confecção do texto foi realizada uma apresentação, dessa vez com uma reportagem selecionada especificamente para a atividade sugerida, que remetia a aspectos da Natureza da Ciência. A matéria escolhida para o encontro é parte da revista Galileu, em sua edição de $\mathrm{n}^{0} 241$, de agosto de 2011, a qual mostra uma reportagem sobre estudos para a possível cura para o autismo.

Nesta reportagem é destacado o trabalho de um biólogo, pesquisador, relatando alguns pontos do seu trabalho, porém, o que realmente chama a atenção na matéria é a imagem central utilizada para ilustrá-la, caracterizada por uma fotografia do referido pesquisador, em que este aparece, em destaque, tendo ao fundo o seu laboratório. Esta ilustração ressalta a visão de um cientista e todos os estereótipos que acompanham esta profissão, como a vestimenta representada pelo jaleco, que, aliás, é a indumentária adequada para este tipo de ambiente, e ao fundo, a paisagem de um laboratório típico, com vários frascos, maquinários, instrumentos e acessórios para experimentos (Figura 1). 
FIGURA 1: Reportagem destacando a figura típica de um cientista no seu laboratório

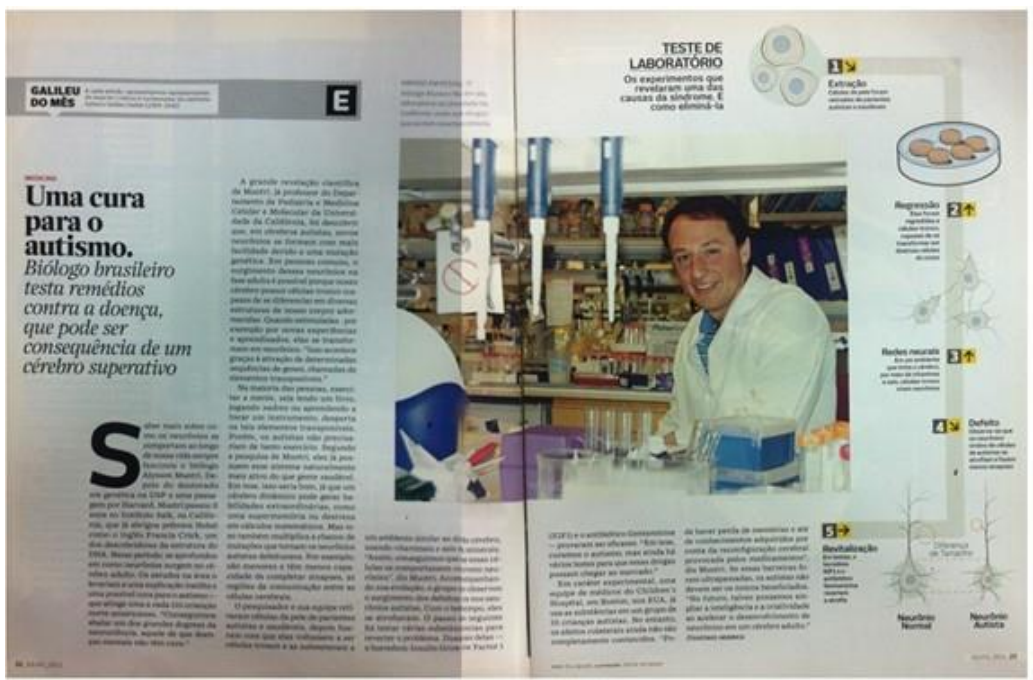

Fonte: Galileu, edição 241. ago/2011.

Além da imagem bastante sugestiva, o texto aborda o estudo como praticamente pertencendo somente a este único pesquisador, ignorando em muitos pontos, o trabalho em equipe e o atendimento a interesses de responsáveis por financiar tal pesquisa. Nesta ocasião, os participantes reconheceram, na própria matéria, os pontos que reforçam os equívocos sobre as concepções da Natureza da Ciência, fato que aconteceu como resultado de uma interessante discussão que objetivou desconstruir a visão equivocada sobre este aspecto. Várias reações de surpresa dos alunos vieram à tona, devido à perplexidade por acabar de descobrir novas compreensões sobre a atividade científica, seu caráter coletivo e de atendimento a interesses diversos.

O terceiro encontro apresentou uma proposta envolvendo textos com temas frequentemente abordados na Biologia Celular, em que o critério para escolha destas reportagens envolveu os recursos imagéticos que as acompanhava, ou seja, as matérias escolhidas deveriam possuir algum tipo de ilustração. A atividade sugerida envolveu a preparação de planos de aula, de acordo com o tema contemplado na reportagem escolhida, os quais poderiam estar voltados para a disciplina Ciências, no segundo segmento do 
ensino fundamental, e para disciplina Biologia, no Ensino Médio. Dentre os textos que foram colocados à disposição dos participantes foram escolhidas, pelos próprios, cinco matérias, provenientes da revista Galileu e da revista Scientific American Brasil.

Estas escolhas levaram em consideração a qualidade e a representatividade que as imagens apresentavam, pois, conforme relatos registrados no diário de bordo, elas contavam com muitos detalhamentos das estruturas celulares. Dois dos planos de aula apresentados, ambos voltados para o primeiro ano do Ensino Médio, possuíam como tema a Citologia, mais precisamente a abordagem da estrutura nuclear. Para ilustrar este planejamento de aula foram utilizadas, como sugestões, as imagens da revista Scientific American Brasil, da edição 106, de março de 2011, mostradas na figura 2 (A e B). As imagens escolhidas indicam, com riqueza de detalhes satisfatória, algumas características relacionadas à molécula de DNA e seus diferentes aspectos morfológicos, a porosidade da carioteca, além do processo de tradução da informação genética em proteínas específicas, promovido pelos ribossomos.

FIGURA 2 (A e B): Referências à organização do núcleo celular
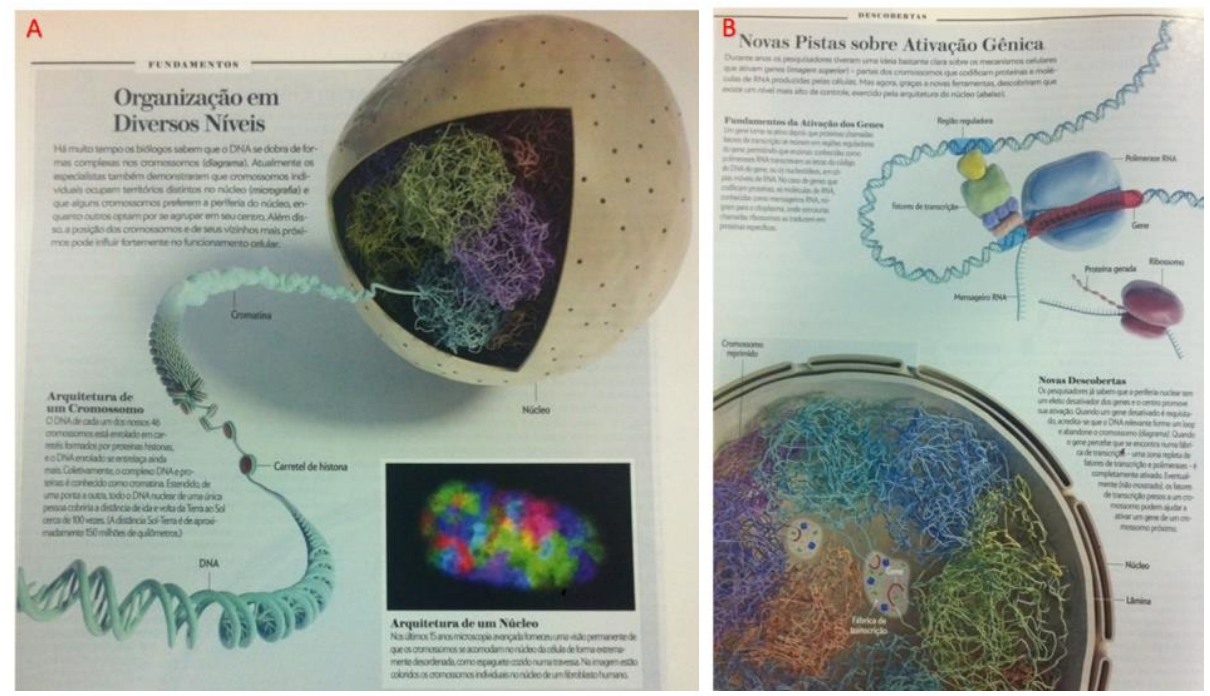

Fonte: (A) Scientific American Brasil edição 106. mar/2011. (B) Scientific American Brasil edição 106. $\operatorname{mar} / 2011$. 
Quatro outros planos de aula produzidos, também voltados para o primeiro ano do Ensino Médio, se propuseram a descrever estratégias de ensino a respeito da membrana plasmática e suas propriedades morfofisiológicas. Para esta abordagem foram utilizadas as imagens da revista Scientific American Brasil, das edições 112, de setembro de 2011 (figura 3-A), e 134, de julho de 2013 (figura 3-B). Cabe ressaltar que a imagem representada pela figura 3-A, apesar de exibir processos que envolvem mutações na codificação de um gene, levando à uma doença conhecida como fibrose cística, consegue mostrar os detalhes moleculares que envolvem a organização da membrana plasmática, facilitando a sua explicação.

$\mathrm{O}$ mesmo acontece com a figura $3-\mathrm{B}$, no tema relacionado à estrutura encefálica. Porém, neste caso, o destaque fica por conta da ilustração que representa um vaso sanguíneo no encéfalo, visto em corte transversal, mostrando detalhadamente as células endoteliais e as suas respectivas membranas plasmáticas, assim como esta membrana atua mediante a fármacos que supostamente tratariam tumores ou representariam terapias para certas doenças degenerativas.

FIGURA 3 (A e B): Referências à estrutura da membrana plasmática.
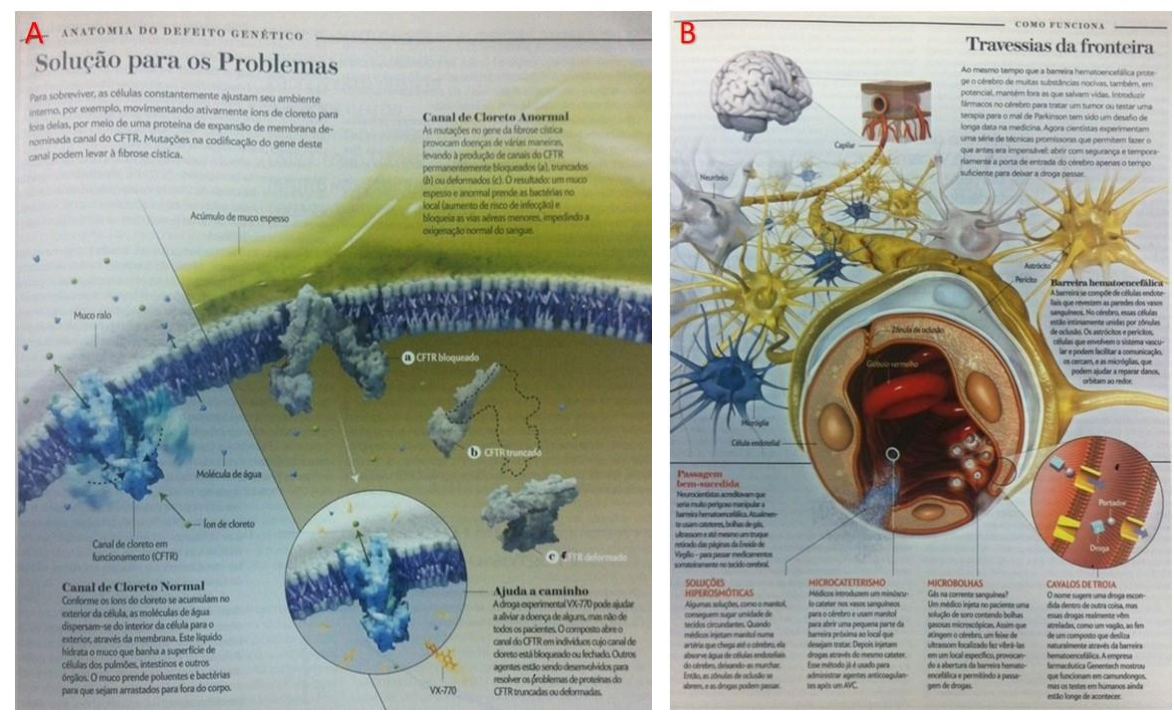

Fonte: (A) Scientific American Brasil edição 112. set/2011. (B) Scientific American Brasil edição 134. jul/2013. 
Dois outros planos de aula utilizaram uma imagem da revista Galileu, da edição 279, de outubro de 2014, mostrada na figura 4. Um deles foi voltado para o oitavo ano do Ensino Fundamental, abordando tecido sanguíneo, uma vez que a imagem traz uma relação com os elementos figurados do sangue - células e plaquetas - com uma breve explicação sobre cada um deles e o seu local de produção. O outro plano de aula, dessa vez voltado para o Ensino Médio, descreveu um planejamento de aula sobre o tecido hematopoiético, onde o aproveitamento da imagem teve os mesmos objetivos, apesar da reportagem abordar uma situação diferente.

FIGURA 4: Representação da medula óssea e os elementos figurados do sangue.

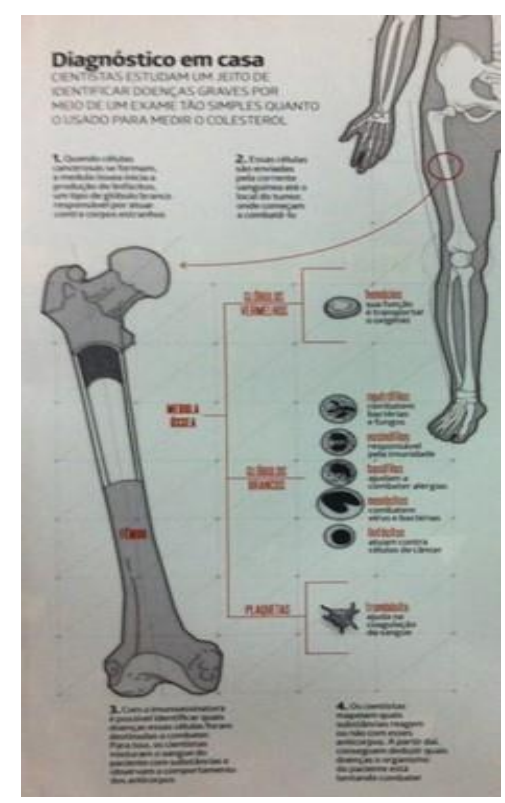

Fonte: Galileu, edição 279. out/2014.

Após lerem as reportagens, os participantes que optaram pelas imagens das figuras 2, 3 e 4 mostraram, ao confeccionar os seus planos de aula, que se atentaram para aspectos inerentes à interdisciplinaridade, discutindo a sua importância e a aplicabilidade em suas aulas (BRASIL, 2000; KRASILCHIK, 2000; KRAWCZYK, 2002), já que, além de abordarem 
o tema "membrana plasmática", ainda levantaram pontos importantes sobre saúde e doença, suas terapias, a produção de fármacos e os processos biotecnológicos, os quais são significativos para a Educação Básica.

A imagem mostrada na figura 5, da revista Galileu, em sua edição de $\mathrm{n}^{\mathrm{o}} 241$, de agosto de 2011, foi utilizada em dois outros planos de aula, ambos relacionados ao $7^{\circ}$ ano do Ensino Fundamental. Um dos planos de aula destacava as células procarióticas em geral. O outro fazia uma abordagem sobre o formato das estruturas bacterianas. Na imagem em questão, estruturas bacterianas colorizadas são percebidas através de uma fotomicrografia extraída de um microscópio eletrônico de varredura, onde se pode destacar o seu formato e vários outros detalhes morfológicos, tornandose, assim, apropriado para o objetivo da aula planejada.

FIGURA 5: Reportagem com destaque para imagem de estruturas bacterianas utilizadas nos planos de aula.

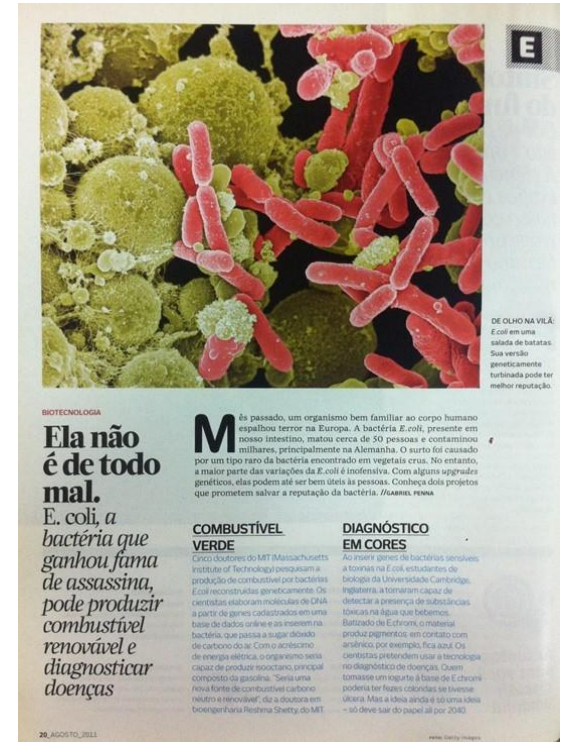

Fonte: Galileu, edição 241. ago/2011.

O quarto encontro envolveu a utilização de reportagens que perpassavam por várias áreas de conhecimento, com uma proposta de discussão entre os participantes para identificação dos temas abordados e a importância do contexto interdisciplinar no ensino de Ciências e Biologia. O 
critério empregado para escolha dos textos que compuseram o material de trabalho referiu-se ao tamanho da reportagem, ou seja, os mesmos deveriam abranger reportagens de destaque, mas que não excedessem mais de uma página, objetivando uma leitura mais dinâmica e que pudesse ser feita durante o próprio dia do encontro. Para este propósito foram escolhidos os textos publicados nas revistas Ciência Hoje, edição 327 de jul/2015; Galileu, edição 282 de Jan/2015; e Scientific American Brasil, edição 155 de $\mathrm{abr} / 2015$.

A matéria extraída da revista Ciência Hoje apresentou uma reportagem sobre um projeto biotecnológico para desenvolvimento de dispositivos extremamente pequenos - nanomoleculares, que de dentro do próprio corpo do paciente poderiam realizar a aplicação gradativa de fármacos, e assim, tratar doenças infecciosas e até mesmo o câncer. O grupo que optou por trabalhar com este texto conseguiu reconhecer as áreas de conhecimento que foram contempladas em suas linhas, porém, isto exigiu que seus integrantes o lessem mais de uma vez para o seu correto entendimento, visto que este texto da revista, especificamente, apresentou uma linguagem mais rebuscada, acrescida de alguns termos técnicos, o que dificultou um pouco a compreensão deles, mesmo em se tratando de estudantes de Biologia concluintes. Esta observação encontra apoio na pesquisa de Gomes (2000), a qual menciona que alguns textos da revista Ciência Hoje têm um perfil de publicação que se destina a divulgar ciência para um público de nível superior, cujo principal segmento seja representado, talvez, pelos os próprios cientistas, não se configurando em um material jornalístico, principalmente quando assinados pelos próprios cientistas colaboradores, diferentemente do que ocorre quando os profissionais da redação se responsabilizam por esta escrita.

O texto da revista Galileu apresenta em sua reportagem um estudo de pesquisadores que, através da utilização de células-tronco, criaram um mecanismo para encontrar e eliminar tumores, sem que, no entanto, o processo causasse prejuízos ou efeitos colaterais para o restante do 
organismo. O grupo de trabalho deste texto percebeu apenas os aspectos relacionados ao câncer, deixando de mencionar todo o viés biotecnológico envolvido no estudo. Este aspecto manifesta duas indagações: a primeira, que apesar da reportagem ser curta, faltou maior atenção e concentração durante a leitura, já que, como parte das suas próprias características, a revista utiliza uma linguagem mais acessível ao público leigo, inclusive, incluindo analogias e metáforas para facilitar esse entendimento; a segunda revela certa incoerência, já que nenhum dos membros desconhece os aspectos biotecnológicos que envolvem os trabalhos científicos, haja vista a atividade voltada para os pontos alusivos à Natureza da Ciência.

Já a matéria pertencente a revista Scientific American Brasil mostra estudos apontando a causa de determinados tipos de cânceres, como sendo originados por infecções virais. Este texto foi escolhido por um grupo que, ao realizar a sua leitura por mais de uma vez, conseguiu perceber todos os temas contemplados na reportagem, apesar da linguagem mais técnica normalmente utilizada por essa revista, revelando um bom progresso em relação à leitura destes participantes.

Após o processo de leitura das reportagens e reconhecimento dos temas próprios da biologia Celular abordados, os participantes confeccionaram um relatório, identificando a importância da interdisciplinaridade no ensino de Ciências e Biologia. Nesta atividade foi possível verificar, com as observações e anotações resgatadas do diário de bordo, que esta proposta teve uma maior e mais fácil assimilação pelos participantes, principalmente após a atividade anterior, onde alguns deles apresentaram planos de aula em que a metodologia e o objetivo central continham procedimentos de ensino que contemplavam várias áreas de conhecimento dentro da Biologia.

A atividade proposta para o encontro cinco objetivou a utilização de matérias contendo incoerências, inconsistências e erros conceituais relacionados aos temas de Biologia Celular. Após a leitura dos textos selecionados, esperava-se, por parte dos participantes, a identificação dos 
erros conceituais que supostamente poderiam ser encontrados, e a posterior preparação de um relatório onde seriam apontadas tais inconsistências.

Para esta atividade foram escolhidas três reportagens da revista Superinteressante, que abordavam temas variados, como estruturas bacterianas, mutação e processos imunológicos, conforme constatado na edição 318, de maio de 2013; na edição especial 305 a, de junho de 2012; e na edição 306, de julho de 2012, respectivamente. Esta se constituiu em uma etapa bastante emblemática e preocupante, pois, ao mesmo tempo em que exigia uma leitura e análise crítica em relação aos conteúdos publicados, traduzidos em temas de interesse comum no que tange ao conhecimento científico e tecnológico, oriundos das biociências, serviu também como instrumento de investigação sobre o atual nível de conhecimento dos futuros profissionais da educação e, consequentemente, agentes multiplicadores nos processos de educação científica.

A preocupação ficou por conta do não reconhecimento dos erros e das inconsistências existentes nos textos. Estas análises corroboraram com as atividades anteriores da SD, onde foram constatadas deficiências em relação à leitura e análise textuais, bem como com o trabalho de Monerat e Rocha (2015), o qual identificou dificuldades apresentadas por estudantes de graduação em relação à aprendizagem de conceitos relacionados à Biologia Celular.

É imprescindível mencionar que o aspecto preocupante também fica por conta do perfil dos participantes desta SD, pois diferentemente do tipo de público que integrou a pesquisa dos autores (op cit), os quais trabalharam com estudantes recém-chegados à graduação, o atual trabalho atua com estudantes concluintes e, consequentemente, futuros professores. Sob estes aspectos identificou-se limitações que se mostraram relevantes no que concerne ao planejamento e aplicação da SD, uma vez que, pelo fato de ter sido aplicada durante o semestre letivo, uma quantidade reduzida de encontros foi planejada para que não houvesse interposição com as datas de avaliações e afins no calendário acadêmico da instituição onde o trabalho foi 
desenvolvido. Assim sendo, a quantidade e o tempo dedicado a cada um dos encontros se fizeram insuficientes para a constatação de algum desenvolvimento no que tange os hábitos de leitura e, consequentemente, de um processo de análise crítica dos conteúdos apresentados nos textos, o que pode ter sido um desencadeador da ainda não construção do pensamento analítico por parte daqueles futuros professores.

De modo geral, as SD também se mostram limitadas pois se subordina a uma realidade já enfrentada por alguns estudantes no que concerne à sua formação básica, resultante, dentre outros fatores, das imensas deficiências no seu desenvolvimento educacional, o que interfere diretamente nas práticas de leitura e consequente entendimento do mundo que o cerca

O sexto e último dia da SD culminou com a confecção de uma mostra de trabalhos, em que todas as produções foram apresentadas, fazendo com que os participantes, na sua totalidade, tomassem conhecimento sobre o que havia sido elaborado pelos demais durante os encontros, o que serviu para uma importante reflexão sobre as atividades realizadas, os diversos recursos da Divulgação Científica que podem ser utilizados em suas aulas e o quanto eles necessitam aprimorar na sua formação para exercer a profissão pretendida.

\section{Considerações finais}

Apesar dos avanços tecnológicos, as mídias impressas ainda despertam interesse junto ao grande público, o que influenciou na construção deste trabalho com revistas de Divulgação Científica impressas, associando-as ao emprego de uma SD junto à estudantes de licenciatura. Periódicos como Ciência Hoje, Galileu, Scientific American Brasil e Superinteressante apresentam grande tiragem e distribuição, seja em relação ao mercado ou mesmo no meio acadêmico. 
Desse modo, os licenciandos participantes do estudo têm a sua disposição mais um instrumento que pode ser utilizado no planejamento de suas práticas, elaborando metodologias de ensino que envolvam, além da Divulgação Científica e a participação ativa dos alunos, o pensamento crítico importante para o Ensino de Ciências e Biologia, conforme recomendam os Parâmetros Curriculares Nacionais, Brasil (2000), e também de acordo com o trabalho de autores como Lapa, Bejarano e Penido (2011), que consideram a criticidade no ensino das ciências uma instância que supera a dicotomia ensino e pesquisa como forma de compreensão e transformação do mundo.

Este estudo permitiu inferir que as SD, apesar do potencial em fazer do aluno o centro do processo de construção do seu conhecimento, também apresentaram algumas limitações, que se fizeram representar principalmente pela quantidade reduzida de encontros e do tempo dedicado a cada um deles, tornando-os insuficientes para o desenvolvimento dos hábitos de leitura e, consequentemente, de um processo de análise crítica dos conteúdos apresentados nos textos, o que pode ter sido um desencadeador da ainda não construção do pensamento analítico por parte daqueles futuros professores. Diante desta constatação, as limitações também estão relacionadas à uma realidade já enfrentada por alguns dos participantes no que concerne o curso educacional básico de cada um deles, provocadas pelas imensas deficiências no seu desenvolvimento pleno, o que interfere diretamente nas práticas de leitura e consequente entendimento da sua realidade.

No entanto, as potencialidades apresentadas podem mostrar-se reais instrumentos de contribuição no processo de formação de licenciandos, por intermédio das atividades propostas para os encontros as quais geraram discussões sobre várias questões que permeiam a construção de saberes necessários à prática educativa. Parte desse processo de amadurecimento pode ser exemplificado por meio das mudanças observadas em suas concepções prévias a respeito da atividade científica e da natureza da ciência, as quais foram se dirimindo e enveredando para uma visão mais 
construtivista a medida que as discussões se intensificaram, tendo como resultado, a produção de textos com maior caráter argumentativo e com uma percepção mais assertiva sobre os tais aspectos, de acordo com Acevedo et al. (2005).

Esta observação, que também encontra apoio no estudo de Scheid, Ferrari e Delizoicov (2007), provavelmente decorre da ausência, durante a formação inicial, de discussões epistemológicas que poderiam contribuir para a compreensão da complexidade da atividade científica. Estas concepções equivocadas da Natureza da Ciência podem repercutir na forma de ensinar temas mais polêmicos, como por exemplo, às terapias celulares, transgênicos, engenharia genética e biotecnologia. Em vista disso, a formação inicial do professor de Ciências e Biologia deve ser pensada de modo a contemplar discussões epistemológicas e filosóficas da Ciência.

A utilização de recursos linguísticos e visuais empregados pela mídia impressa em suas reportagens tiveram boa aceitação por parte dos licenciandos, pois foram amplamente utilizados na produção de materiais de grande potencial para atividades em sala de aula, podendo, inclusive, fazer parte de seus planejamentos para o Ensino de Ciências e Biologia

Outro ponto de atenção ficou por conta das atividades que discutiam as potencialidades dos textos que exigiam uma leitura e análise crítica das reportagens, onde todas refletiam temas de interesse relacionados ao conhecimento científico e tecnológico, provenientes das biociências. Alguns destes textos continham erros conceituais e inconsistências na publicação das informações que não foram reconhecidos pelos participantes, o que demanda especial atenção e um olhar mais crítico no que tange às futuras práticas de leitura destes graduandos.

A partir destes aspectos, a SD permitiu perceber que estes futuros professores devem repensar a sua leitura, e se apropriar de forma mais aprofundada dos materiais de Divulgação Científica, ressignificando-os para sua possível utilização em atividades de leitura, confecção de textos e planos de aula, facilitando o planejamento das suas atividades de ensino. 
Portanto, as SD se constituem em metodologias adequadas para diagnosticar as dificuldades, os interesses e as potencialidades dos alunos em relação a um determinado conteúdo, além de propiciar ao professor, uma análise sobre o que foi ressignificado, a partir do conjunto de atividades e produções realizadas, corroborando com o trabalho de autores, como Dolz, Noverraz e Schneuwly (2004); Zabala e Arnau (2007); Giordan, Guimarães e Massi (2011), podendo, portanto, serem consideradas como instrumentos de planejamento do ensino e também como objetos de pesquisa da prática docente, com seus potenciais de formação através da adoção de métodos pertinentes para a construção de saberes científicos, oportunizando ao futuro professor refletir sobre o seu próprio processo de aprendizagem.

\section{Referências}

ACEVEDO, J. A. et al. Naturaleza de la ciencia y educación científica para la participación ciudadana: una revisión crítica. Revista Eureka sobre Enseñanza y Divulgación de las Ciencias, Cádiz, v. 2, n. 2, p. 121-140, 2005.

BARDIN, L. Análise de Conteúdo. 1. ed. Lisboa: Edições 70 - LDA, 2009.

BRASIL. Ministério da Educação. Parâmetros Curriculares Nacionais para o Ensino Médio (PCNEM): Ciências da Natureza, Matemática e suas Tecnologias. Brasília: 2000.

BUENO, W. C.; Jornalismo científico: revisando o conceito. In: VITOR, C.; CALDAS, G.; BORTOLIERO, S. (Org.). Jornalismo científico e desenvolvimento sustentável. São Paulo: All Print, 2009. p. 157-178.

DOLZ, J.; NOVERRAZ, M.; SCHNEUWLY, B. Sequências didáticas para o oral e a escrita: apresentação de um procedimento. In: ROJO, R.; CORDEIRO, G. (Orgs.). Gêneros orais e escritos na escola. Campinas: Mercado de Letras, 2004. p. 95-128.

FERREIRA, S. P. A.; SANTOS, E. de M. Constituição do professor-leitor: condições e compreensão de leitura em alunos universitários. Revista Psicologia, São Paulo, v. 12 , n. 2 , p. $96-111,2010$.

GIL, A. C. Como elaborar projetos de pesquisa. São Paulo: Atlas, 2008.

GIORDAN, M., GUIMARÃES, Y. A. F.; MASSI, L. Uma análise das abordagens investigativas de trabalhos sobre sequências didáticas: Tendências no ensino de Ciências. In: Atas do VIII Encontro Nacional de Pesquisa em Educação em

Ciências, Campinas, 2011. 
GOLDBACH, T.; EL-HANI, C. N. Entre Receitas, Programas e Códigos: Metáforas e Idéias Sobre Genes na Divulgação Científica e no Contexto Escolar. Alexandria: Revista de Educação em Ciência e Tecnologia, Florianópolis, v.1, n.1, p. 153-189, 2008.

GOMES, I. M. de A. M. A Divulgação Científica em Ciência Hoje: características discursivo-textuais. 2000. 306f. Tese (Doutorado em Linguística)-Faculdade de Letras. Universidade Federal de Pernambuco, Recife, 2000.

KEMPER, A.; ZIMMERMANN, E.; GASTAL, M. L. Textos populares de divulgação científica como ferramenta didático-pedagógica: o caso da evolução biológica.

Revista Brasileira de Pesquisa em Educação em Ciências, Belo Horizonte, v. 10, n. 3, p. 25-50, 2010.

KLEIMAN, A. Texto e leitor: Aspectos cognitivos da leitura. 2. ed. Campinas: Pontes, 2000.

KRASILCHIK, M. Reformas e realidade: o caso do ensino das ciências. São Paulo em Perspectiva, São Paulo, v. 1, n. 14, p. 85-93, 2000.

KRAWCZYK, N. A sustentabilidade da reforma educacional em questão: a posição dos organismos internacionais. Revista Brasileira de Educação, n. 19, p. 43-62, 2002.

LAPA, J. M.; BEJARANO, N. R.; PENIDO, M. C. M. Interdisciplinaridade e o ensino de ciências: uma análise da produção recente. In: Atas do VIII Encontro Nacional de Pesquisa em Educação em Ciências, Campinas, 2011.

MARTINS, I.; CASSAB, M.; ROCHA, M. B. Análise do processo de re-elaboração discursiva de um texto de divulgação científica para um texto didático. Revista Brasileira de Pesquisa em educação em Ciências, Belo Horizonte, v. 1, n. 3, p. 1927, 2001.

MARTINS, I.; NASCIMENTO, T. G.; ABREU, T. B. Clonagem na sala de aula: um exemplo do uso didático de um texto de divulgação científica. Investigações em Ensino de Ciências, Porto Alegre, v. 9, n. 1, p. 95-111, 2004.

MONERAT, C. A. A.; ROCHA, M. B. Análise da percepção de estudantes de graduação da área da saúde sobre o tema Biologia Celular. Revista de Ensino de Bioquímica, São Paulo, v. 13, n. 1, p. 27-44, 2015.

Como a Biologia Celular tem Sido Abordada por Revistas de Divulgação Científica. Contexto \& Educação, Ijuí, v. 33, n. 105, p. 27-51, 2018.

MONTEIRO, S. M.; SOARES, M. Processos cognitivos na leitura inicial: relação entre estratégias de reconhecimento de palavras e alfabetização. Educação $e$ Pesquisa, São Paulo, v. 40, n. 2, p. 449-466, 2014. 
MOREIRA, I de C. A inclusão social e a popularização da ciência e tecnologia no Brasil. Inclusão Social, Brasília, v. 1, n. 2, p. 11-16, 2006.

SANTOS, M. V. M. dos. A leitura como prática cotidiana e motivacional: da infância ao crescimento intelectual e discernimento crítico. Revista $A C B$ do movimento associativo de bibliotecários, Florianópolis, v. 11, n. 1, p. 29-37, 2006.

SCHEID, N. M. J.; FERRARI, N.; DELIZOICOV, D. Concepções sobre a natureza da ciência num curso de ciências biológicas: imagens que dificultam a educação científica. Investigações em Ensino de Ciências, Porto Alegre, v.12, n. 2, p. 157-181, 2007.

TRIVIÑOS, A. N. S. Introdução à pesquisa em ciências sociais: a pesquisa qualitativa em educação. 1. ed. São Paulo: Atlas, 1987.

ZABALA, A. Prática Educativa: como ensinar. 1. ed. Porto Alegre: Artmed, 1998.

ZABALA, A.; ARNAU, L. La enseñanza de las competencias. Revista Aula de innovación educativa, La Rioja, n. 161, p. 40-46, 2007.

Recebido em dezembro de 2019.

Aprovado em maio de 2020. 